\title{
Why Magic Cannot Be Falsified By Experiments
}

\section{Benedek Láng, Budapest University of Technology and Economics ${ }^{1}$}

Introduction

Medieval texts on natural magic, talismans, divination, and angel magic report practical methods (often called as experiments: experimenta) that the modern reader will find at best curious, if not unreal. The Liber aggregationis (The Book of Collections) attributed to Albertus Magnus explains that by collecting and preparing certain herbs appropriately, one will be addressed only with friendly words, and one can even become invisible. The book claims that the magnet has the property of revealing whether one's wife is chaste and that by using the tongue of the sea-cow a person can prevent others from having bad opinions him. ${ }^{2}$ A tract on geomancy attributed to Gerard of Cremona provides divinatory tools that can be used if we want to learn whether the king will die. ${ }^{3}$ The De imaginibus attributed to Thabit ibn Qurra recommends the use of talismans if one wants to destroy a city or to expel scorpions from the town. ${ }^{4}$ The anonymous Ars notoria suggests that following a long ritual program composed of prayers and various pious actions, the student can master the seven

\footnotetext{
${ }^{1}$ My research was supported by two Hungarian grants, the OTKA K 101544 and the Bolyai János Postdoctoral Fellowship. Let me thank the anonymous readers of my article and the editors of this volume for their constructive remarks.

${ }^{2}$ For the experiments of the Liber aggregationis, see Isabelle Draelants, Le liber de virtutibus herbarum lapidum et animalium (Liber aggregationis) (Florence: Sismel, 2007).

${ }^{3}$ Thérèse Charmasson, Recherches sur une technique divinatoire: la geomancie dans l'Occident medieval (Geneva: Librarie Droz, 1980), 63-64. See also Charmasson, "Les premiers traites latins de geomancie," Cahiers de civilisation medievale 21 (1978): 121-36.

${ }^{4}$ For an edited version of the text, see Francis J. Carmody, ed., The Astronomical Works of Thabit ben Qurra (Berkeley: University of California Press, 1960), 180-94.
} 
liberal arts very quickly. ${ }^{5}$ Certain anecdotes written in the end of the fourteenth century tell a story in which Thomas of Pizan--doctor of astrology and medicine in the service of the French king, Charles V--successfully used planetary talismans engraved with the names of angels to expel the English army from French territory. ${ }^{6}$

These proscriptions are not curiosities or exceptions in the medieval literary corpus. Many such texts and stories were widespread in the Middle Ages as well as early modern times: learned monks, court intellectuals, and university masters--that is, intelligent individuals capable of reflection--copied and collected them. ${ }^{7}$ Even though we cannot exclude the possibility that some of these thinkers had a certain skepticism concerning certain methods, there is no reason to doubt that most of these texts were copied with a fairly strong conviction that the procedures outlined in them were valid. To be sure, in some cases, the author or scribe simply wished to create a beautiful, fascinating, or entertaining book that was not meant to be a manual for actual use. At times the copyist's motive might have simply been to collect interesting stories and experiments that he could later tell his seigneur, bishop, students, wife, or children. While this is certainly true in some instances, most of the times

\footnotetext{
${ }^{5}$ Julien Veronese, L'Ars notoria au moyen age: introduction et edition critique, Micrologus Library 21 (Florence: Sismel, 2007); Jean-Patrice Boudet, "L'Ars notoria au Moyen Age: une resurgence de la theurgie antique?", in La Magie: Actes du colloque internatonal de Montpellier 25-27 Mars 1999, vol. 3 (Montpellier: Universite Paul-Valery, Montpellier III, 2000), 173-91.

${ }^{6}$ Nicolas Weill-Parot, Les "images astrologiques" au Moyen Âge et à la Renaissance: Speculations Intellectuelles et pratiques magiques (XIIe-XVe siècle) (Paris: Honoré Champion, 2002), 605; Jean-Patrice Boudet, Le Recueil des plus célèbres astrologues de Simon de Phares édité pour la société de l'Histoire de France, 2 vols. (Paris, 1997-1999), $2: 257$.

${ }^{7}$ For the "social history of magic," see among others: Richard Kieckhefer, Magic in the Middle Ages (Cambridge: Cambridge University Press, 1989); idem, Forbidden Rites: A Necromancer's Manual of the Fifteenth Century (Stroud: Sutton, 1997); Jean-Patrice Boudet, Entre science et "nigromance". Astrologie, divination et magie dans l'Occident médiéval (XIIe-XVe siècle) (Paris: Publications de la Sorbonne, 2006); and Benedek Láng Unlocked Books: Manuscripts of Learned Magic in the Medieval Libraries of Central Europe (University Park: Penn State University Press, 2008).
} 
the codicological context of the magic texts (the fact that they were copied next to practical scientific texts), the marginal notes, and various extra-codicological information indicate that these texts were generally meant for actual use.

The question I want to ask is the following: Why didn't the scribes and collectors see that it was impossible to become invisible with the help of herbs, that it was impossible to learn the seven liberal arts through the prayers of the Ars notoria, that it was impossible to expel scorpions from Bagdad or destroy cities with the help of Thabit's De imaginibus, and that the magnet does not say anything about the chastity of their wives? ${ }^{8}$ How did these persons fail to recognize that the methods they were copying were nonsense? Did they not see that the mechanism of magic is obviously false, and that its falsity can be easily shown in practice with the help of simple experiments?

Before trying to address this question, however, certain meta-level considerations have to be explored. Specifically, is such a question legitimate at all, or is it desperately naïve and anachronistic?

The answer depends on the perspective of the answerer. For a traditional positivistic-or rather Popperian--scholar, for example, such a question can be seen as legitimate, but somewhat uninteresting. All the experiments described above would be seen either as clearly falsified by simple counterevidence or as pseudo-scientific in the sense that they avoid empirical falsification with the help of ad hoc hypotheses. Karl Popper had famous examples for both cases. He called astrology and Marxism pseudo-scientific in the first sense: they make predictions that prove false in front of the tribunal of empiria, yet advocates of these "disciplines" avoid taking this falsification seriously:

\footnotetext{
${ }^{8}$ My earlier attempt to answer this question can be found in my monograph, Unlocked Books, 270-72. As the present article is a further elaboration on the same question, I occasionally incorporated ideas in the argumentation that already appeared in the monograph.
} 
Astrology did not pass the test. Astrologers were greatly impressed, and misled, by what they believed to be confirming evidence--so much so that they were quite unimpressed by any unfavourable evidence. Moreover, by making their interpretations and prophecies sufficiently vague they were able to explain away anything that might have been a refutation of the theory had the theory and the prophecies been more precise. In order to escape falsification they destroyed the testability of their theory. It is a typical soothsayer's trick to predict things so vaguely that the predictions can hardly fail: that they become irrefutable. ${ }^{9}$

The case with Marxism is quite similar:

The Marxist theory of history, in spite of the serious efforts of some of its founders and followers, ultimately adopted this soothsaying practice. In some of its earlier formulations...predictions were testable, and in fact falsified. Yet instead of accepting the refutations the followers of Marx re-interpreted both the theory and the evidence in order to make them agree. In this way they rescued the theory from refutation; but they did so at the price of adopting a device which made it irrefutable. ${ }^{10}$

In these two cases the followers of the criticised disciplines systematically resisted counterevidence. Psychoanalysis, on the other hand, is pseudo-scientific in Popper's second sense:

The psycho-analytic theories were in a different class. They were simply non-testable, irrefutable. There was no conceivable human behaviour which could contradict them. ${ }^{11}$

\footnotetext{
${ }^{9}$ Karl Popper, Conjectures and Refutations: The Growth of Scientific Knowledge (London: Routledge and Keagan Paul, 1963), 37.

${ }^{10}$ Ibid.

${ }^{11}$ Ibid.
} 
The theories of this discipline--Popper argues--are constructed in a way that they simply avoid any possible empirical falsification.

The post-Popperian period, however, reconsidered the question, and Popper's theories of falsification and of demarcation were seriously challenged. They received famous criticisms from theorists such as Imre Lakatos and Larry Laudan. On the on hand, Lakatos argued that many genuine scientific theories are immediately falsified after their birth. This does not mean, however, that scientists get rid of them; just the opposite, a constructive reaction to the falsificatory attempts can allow theories to develop in ways that allow them to conform to the empiria better. Thus, newly introduced auxiliary hypotheses that make theories more resistant to empirical refutation is not a characteristic of pseudo-science, it is also an important constituent of scientific activity. ${ }^{12}$ Laudan, on the other hand, famously called the whole issue of demarcation a pseudo-problem. He maintained the difference between good and bad, between reliable and unreliable science, but he rejected the notion of universal standards, necessary and sufficient conditions, according to which science and pseudo-science could be differentiated. ${ }^{13}$ While Laudan's claims have been challenged by a number of philosophers, his argument that purely epistemic criteria cannot differentiate science from pseudo-science has been largely accepted. We can also mention the name Pierre Duhem, whose thesis of underdetermination undermined the theory of falsification a half century before it was formulated at all. ${ }^{14}$ Duhem, a former practicing scientist himself, called

\footnotetext{
${ }^{12}$ Imre Lakatos, "Falsification and the Methodology of Scientific Research Programmes", in Imre Lakatos and Alan Musgrave, eds., Criticism and the Growth of Knowledge (Cambridge: Cambridge University Press, 1970), 91-196.

${ }^{13}$ Larry Laudan, "The Demise of the Demarcation Problem," in R. S. Cohen and Larry Laudan, eds. Physics, Philosophy and Psychoanalysis: Essays in Honor of Adolf Grünbaum (Dordrecht: D. Reidel, 1983), 111-127.

${ }^{14}$ Pierre Duhem, La théorie physique, son objet et sa structure (Paris: Chevalier \& Rivière, 1906), the English translation of the second, 1914 edition: The Aim and Structure of Physical Theory (Princeton: Princeton University Press, 1954.)
} 
attention to the fact that scientific theories never occur individually. Each theory consists of a group of interconnected theoretical clams and considerations, and when a given theory seems to be falsified by experimental results, one can never know precisely which part of the network of claims is responsible for the negative results. Where exactly the scientist is required to emend his theory, or which part of it they have to get rid of, is--philosophically speaking--underdetermined.

In the 1960s, partly as a result of Thomas Kuhn's works, the philosophy of science underwent an historical turn, and questions concerning the falsifiability of earlier belief systems were disqualified. The argument was made that such questions fell into the error of presentism, or Whiggish history. Whig history is--by definition--unhistorical history writing. The presentist historian of science (or historian of magic) writes about the past in terms of the present, judging phenomena from the history of science in terms of present-day science. In its worse forms, the Whiggish position conceives the past as a mere preparation for the present. ${ }^{15}$ In the case of alchemy, for example, this attitude leads to the famous evolutionary theory according to which alchemy was a partly mistaken, partly ridiculous, yet partly useful protochemistry (useful to the extent that it helped uncover phenomena now considered valid). In the case of magic, the Whiggish historian would either look for some proto-scientific details in magic (its experimental nature or its seemingly universal laws) or see it purely as a dead end. Even the famous scholar of magic Lynn Thorndike might be accused of some Whiggishness. In one of his few theoretical considerations, Thorndike tried to legitimize his subject with presentist arguments. He praised astrology for formulating the only universal

${ }^{15}$ On Whiggism, anti-Whiggism and anti-anti Whiggism, see Helge S. Kragh, An Introduction to the Historiography of Science (Cambridge: Cambridge University Press, 1989), 93-94; Thomas Nickles, "Philosophy of Science and History of Science," in Osiris, 2nd ser., vol 10 (1995) (the issue is entitled "Constructing Knowledge in the History of Science" and is edited by Arnold Thackray), 139-163; and Stephen G. Brush, "Scientists as Historians," ibid., 214-231. 
law of nature before Newton, namely that celestial beings exercise power on the terrestrial ones. ${ }^{16}$ However, a universal law is important and relevant only in post-Newtonian science; to describe earlier phenomena with this term is simply anachronistic. Thorndike also wrote: $\ldots$ in works of the fourteenth and fifteenth centuries might be found the germs of later scientific discoveries. We have seen the conception of gas already current among the alchemists, to say nothing of scholastic discussion of density and rarefaction. Various theories of attraction and gravitation have been put forward to explain the influence of the moon on tides or the suspension of our globe in mid-space.... We have heard a theory of the circulation of the spirits somewhat resembling the circulation of the blood. ${ }^{17}$

Similar Whiggism characterized the work of Karin Figala, who rationalized Isaac Newton's alchemical activity by claiming that it resembled early twentieth century atomic theories, particularly the atomic shell model of Niels Bohr. ${ }^{18}$ Even the famous thesis of Frances Yates was Whiggish when she defended Hermetic magic as the predecessor of

\footnotetext{
${ }^{16}$ Lynn Thorndike, A History of Magic and Experimental Science (New York: Macmillan, 1923-1958, vol. 4. 1934), 611-615.

${ }^{17}$ Ibid., 612. To be fair, we should also quote Thorndike's final paragraph from the same chapter: "Frankly, it is not for this contribution towards modernity that we most prize these writings of two remote centuries which we have been at some pains to decipher and to set forth. We have taken them as we have found them and we esteem them for what they are in their totality, their fourteenth and their fifteenth century complexio--a chapter in the history of human thought. Read it and smile or read it and weep, as you please. We would not credit it with the least particle of modern science that does not belong to it, nor would we deprive it of any of that magic which constitutes in no small measure its peculiar charm. Perhaps it would be well to read it and think of what the future historian may say of the mentality and scholasticism of the present era and with what sympathy or antipathy he would be justified in regarding us.” Ibid., 615.
}

${ }^{18}$ Karin Figala, "Newtons rationale System der Alchemie," Chemie in unserer Zeit 12 (1978): 101-110. 
modern science. ${ }^{19}$ For a contextualist scholar--someone who rejects Whiggish arguments-these are not acceptable approaches, since scientific (and other) enterprises should not be evaluated according to their afterlife, but according to the standards of the given historical context.

The Whiggish attitude became by and large unacceptable. Over the last forty years historians have tended to follow the prescription Thomas Kuhn offered in his encyclopedia article on the history of science:

Insofar as possible (it is never entirely so, nor could history be written if it were), the historian should set aside the science he knows. His science should be learned from the textbooks and journals of the period he studies. ${ }^{20}$

Such considerations have led to a healthy anti-Whiggish attitude in the history of science, cultural studies, and many other fields. It has made us more tolerant of cultures and epochs alien from our own. It has helped historians understand seemingly nonsensical scientific theories and reconstruct historically changing, dynamic categories (among them, "science," "religion" and "magic"). And it has helped minimize ahistorical explanations in history writing.

Contextualism's impact on magic and witchcraft scholarship has been recently summarized by Stuart Clark. These two fields, he argues, "present, as few other historical subjects do, the challenge of interpreting and understanding things in the past without any

\footnotetext{
${ }^{19}$ Frances Yates, "The Hermetic Tradition in Renaissance Science," in Charles S. Singleton, ed. Art, Science and History in the Renaissance (Baltimore: John Hopkins, 1968), 255-274; Floris Cohen, The Scientific Revolution: A Historiographical Inquiry (Chicago: University of Chicago Press, 1994), 286-296; Wouter Hanegraaff, "Beyond the Yates Paradigm: The Study of Western Esotericism between Counterculture and New Complexity," Aries, Journal for the Study of Western Esotericism 1 (2001): 5-37; Randall Styers, Making Magic: Religion, Magic, and Science in the Modern World (Oxford: Oxford University Press, 2004), 152-163.

${ }^{20}$ Thomas Kuhn, "History of Science" International Encyclopedia on the Social Sciences, vol. 14 (New York: MacMillan, 1968), 74-83.
} 
attempt whatsoever to say whether anything about them was or was not real." 21 This agnosticism--advocated by most magic scholars in the last two or three decades--avoids making claims on past or present reality and concentrates instead on the beliefs of historical actors without evaluating them and without comparing them with our own beliefs. Without this agnosticism, serious scholarship on magic would have never been born.

The importance of the anti-Whiggish approach in history of science cannot be exaggerated, and the constant need for it in science education and the popularization of history of science is undeniable. However, as several authors have argued in the last two decades, anti-Whiggism in professional history of science appears to have run its course. ${ }^{22}$ As it gradually defeated the old positivistic attitude, historians realized something that Kuhn had already referred to in his article, namely that it is not so simple to follow the anti-Whig agenda, and what is more, such a program is not always even desirable. First of all, historians can never forget about present-day science; they will be always a bit more interested in what became a successful trend in the history of science than what proved to be a dead end. They will be more interested in Newton's kinematics than in Descartes'. Second, historians write for a present-day audience and use neologisms, modern categories that were not used and often did not even have equivalents in the past. They are interested in the history of Greek "mathematics" even though this discipline as a separate entity is not an antique category. They write about the "theory of evolution" in regards to Darwin, even though Darwin hardly ever used this term. Third, historians do not even want to give up their right to approach the past through concepts rooted in the present. Histories of childhood, gender, women, and

\footnotetext{
${ }^{21}$ Stuart Clark, “One-Tier History,” Magic, Ritual, and Witchcraft 5(1) (2010): 84-91 (emphasis in original).

${ }^{22}$ Nickles, "Philosophy of Science and History of Science"; and Brush, "Scientists as Historians."
} 
everyday life would not be legitimate themes in a dogmatic application of anti-Whiggism, as these are not genuine categories of many of the ages under study.

All in all, today an anti-anti-Whig position is popular in the history of science.

Nothing is more alien to contemporary scholars than a return to Whiggism, but contemporary historians also warn against the harmful effects of doctrinaire contextualism, an approach that permits only the use of categories and questions raised in the period under study.

Contemporary scholarship permits historians to ask questions inspired by the concerns of the present, but--in contrast to older Whiggish historians--refrain from giving answers distorted by the same concerns. ${ }^{23}$

What about anti-anti-Whiggism in scholarship on magic? Without implying that antiWhiggism has run its course also in magic studies, and without implying that it is no longer needed in fields related to witchcraft, alchemy, astrology, and magic, I believe that the time has arrived when anti-anti-Whig questions can and should be raised. My inquiry into medieval and early modern magic is inspired by this understanding of anti-anti-Whiggism. I believe that one can freely raise the naive question concerning falsifiability with which I began, even though there is clearly something anachronistic in such an inquiry. One only has to be careful when answering this question. This approach is fairly rare in magic scholarship. Recently Edward Bever has asked, "what basis did early modern beliefs about witchcraft and magic have in reality?" 24 In contrast to his substantial investigations that integrate the results of psychology, neuro-physiology, and cognitive science in the field of history of magic, in

\footnotetext{
${ }^{23}$ Kragh, An Introduction, 104.
}

${ }^{24}$ Edward Bever, The Realities of Witchcraft and Popular Magic in Early Modern Europe: Culture, Cognition, and Everyday Life (Basingstoke: Palgrave Macmillan, 2008), xiv. In fact, the objective of Bever's project is to answer three interrelated questions: "First, to what extent did people really engage in and experience the things contained in the beliefs? Second, to what extent did their activities have real effects, and their perceptions reflect objective events? Third, to the extent that their perceptions did not reflect external reality, what were the actual sources and nature of these subjective experiences?" Ibid. 
my considerably shorter study, I situate my basic question rather in the context of history of science. My aim is not to reconstruct what might have happened in a magic experiment, but rather to imagine what the perception of the person who carried out the experiment might have been. I would like to understand how it was possible that historical actors did not see a given experiment as a falsification of related magic theories. I would like to explain for the modern reader how historical actors could have handled the discrepancy between what might have happened in an experiment from our modern perspective and what those historical actors expected. ${ }^{25}$ What is shared in my analysis and that of Bever--apart from asking heterodox questions--is the conviction that medieval and early modern claims about magical efficacy should not be understood as imaginary, but taken as "real."26

\section{An Anti-anti-Whig Approach to Magic Experiments}

Arriving at the point that an attempt can be made finally to address my initial question, it must be noted that we are not looking for one single explanation for why theories of magic were not falsified by negative experiments, but rather for a group of interconnected answers. First, there is no reason to doubt that in many cases magical practices actually worked, producing the desired aims. In such cases magical techniques were certainly regarded by the practitioners as valid methods that led to success. Women sometimes fell in love with someone who previously cast a love spell, armies sometimes occupied castles after someone used talismanic magic, and the number of scorpions sometimes decreased in a city after someone applied a method described in a book on talismans. Such instances were

\footnotetext{
${ }^{25}$ With the last qualifications, I hope to avoid some problematic issues related to the use of "reality" discussed in the fascinating debate about Bever's monograph, see Magic, Ritual, and Witchcraft 5(1) (2010): 81-121.

${ }^{26} \mathrm{Cf}$. the issue of the present article with the central question of Jonathan Z. Smith's "I Am a Parrot," History of Religions 11(4) (1972), 391-413, particularly: "How should the historian of religion interpret a religious statement which is apparently contrary to fact?" on page 393.
} 
certainly viewed as positive cases confirming the efficacy of magic. One should not forget that the methods described in the widespread handbooks of natural and talismanic magic were not as foreign to the medieval and early modern natural philosophy as they seem to be to modern natural science. The underlying assumptions behind the mechanism of talismans and magic stones, the occult virtue of herbs, and the healing power of animal substances formed part of the same correspondential worldview that was typical to many fields of medieval science.

Nevertheless, while we can assume that magical practices led to many positive results and thus produced confirming experiments, we should also assume that in many cases these techniques manifestly did not work. When trying to understand why such negative examples did not destroy the practitioners' belief in magic, we have to differentiate the various types of magic. Let us first consider ritual magic, which addresses spiritual powers (angels, demons, or spirits) through prayers and conjurations. To ask why the practitioner of such a method did not become disillusioned when his or her prayers to the spirits did not influence the earthly events is just as irrelevant as to ask Christian believers whether they become atheists if their prayers remain unanswered by God. Faith in spiritual beings and entities obviously requires different kinds of proof from that needed for scientific convictions, not least because God, angels, and demons are usually seen as conscious beings as opposed to the mechanical processes of science. It sounds fairly absurd to construct scientific experiments in order to test the efficacy of prayers and to count the percentage of those prayers that prove successful. Yet such an experimental approach to testing the percentage of successful prayers was actually proposed by the "science-manager" John Tyndall (1820-1893) in late nineteenth century England, and--quite understandably--this proposal provoked a fairly heated debate 
and important conflict between science and religion. ${ }^{27}$ The proposed experiment was never carried out, not least because it seemed just as absurd in the nineteenth century as today to try to falsify religious beliefs with controlled experiments. ${ }^{28}$

If ritual magic does not seem to be a field where experiments might possess relevant falsificatory power, natural magic, which embraces a wide range of what is called “experimenta literature," would appear a more promising territory for experimental confirmation. Yet as we turn to this field, I should underscore a basic discrepancy between the medieval and the present scientific attitude. In medieval natural philosophy, eagerness to disqualify procedures that systematically failed to produce the expected results was not a particularly central idea. The notion of "experiment" was not understood to be something involving a number of controlled experimental situations, but rather as a commonly shared knowledge described by traditional philosophers and authorities. ${ }^{29}$ Experience was used in scholarly arguments, but in a different manner from the present day. ${ }^{30}$ For example, it was experience that was called upon to prove the existence of demons, and quite understandably, since the existence of spiritual entities was indeed a commonly shared conviction in the

${ }^{27}$ Frank M. Turner, "Rainfall, Plagues, and the Prince of Wales: A Chapter in the Conflict of Religion and Science," Journal of British Studies 13 (1974): 46-95, particularly: 64, quoted by Thomas F. Gieryn, "Boundary-Work and the Demarcation of Science from Non-Science: Strains and Interests in Professional Ideologies of Scientists," American Sociological Review 48 (1983): 781-795.

28 Although similar experiments on the efficacy of forms of "distant healing" (prayer, mental healing, therapeutic touch, or spiritual healing) have been conducted recently: see John Astin, et al, "The Efficacy of 'Distant Healing:' A Systematic Review of Ramdomized Trials," Annals of Internal Medicine 132 (2000): 908-10. I say thank you to Edward Bever for calling my attention to this article.

${ }^{29}$ Láng, Unlocked Books, chap. 2.

${ }^{30}$ On the modern history of the word experience, see Peter Dear, Discipline and Experience, The Mathematical Way in the Scientific Revolution (Chicago: University of Chicago Press, 1995), particularly 11-25. 
Middle Ages. ${ }^{31}$ The main source for the so-called experimenta literature in the Middle Ages was what ancient books and authorities claimed; actual experience, repeated experiments, and actual counterexamples did not play a considerable role in judging the authenticity of the recipes. The experimenta literature (which was the wider context of natural magical recipes) was a textual tradition that should not be conceived as a practical genre, but as "theoretical literature that speaks about practice." ${ }^{, 32}$

As we reconstruct this notion of experiment, it becomes easier to understand why and how relatively fantastic convictions could be considered for centuries as sufficiently--and experimentally--confirmed scientific facts. Authors from Plutarch to the sixteenth century famously referred to the conviction that magnets will loose their power of attraction if they are rubbed with garlic. They did not see this as a claim that had to be proved, but rather they used this accepted "fact" as a "proof" for the theory of antipathies. A congenial worldview (in this case the theory of sympathies and antipathies) and a sufficiently strong textual tradition were more efficient means for this conviction to gain epistemological status than practical tests. Furthermore, several authors explicitly claimed that they had actually tried the magnetgarlic antipathy in practice, and they said it did work. The very same empirical approach that is assumed today to falsify the theory became its actual proof. As Daryn Lehoux convincingly argued, this proof lost its status only in early modern times, when the generally

${ }^{31}$ For the fifteenth-century chancellor of the University of Paris, Jean Gerson, "experientia docuit" the existence of demons. See idem, Opera omnia, "Trilogium," 21. Propositio:

"Oppositum posuerunt qui negaverunt daemones esse...fuerunt etiam experientiae multae in oppositum." On Gerson's use of "experiments" and "experience," see Benedek Láng, "Experience in the Anti-astrological Arguments of Jean Gerson," in Thomas Bénatouil and Isabell Draelants, eds., Expertus sum. L'expérience par les sens dans la philosophie naturelle médiévale. Actes du colloque international de Pont-à-Mousson, 5-7 février 2009 (Firenze, Edizioni del Galluzzo - SISMEL (Micrologus’ Library), 2010, 309-321.

32 I borrowed this characterization from Isabelle Draelants' paper given at the Warburg Institute, May 1, 2002, "The Liber aggregationis (Experimenta/Secreta): Another Link between Albert the Great and Arnoldus Saxo?" 
accepted ontology of the world was transformed and magnets and garlic were no longer seen as having antipathies and sympathies (instead one came to be seen as having magnetic force, and the other as being completely irrelevant as far as magnetism is concerned). Things are proved to be non-existent and theories are proved to be false only when they change their status in the classificatory framework of a new world-view. ${ }^{33}$

The solution is not much more straightforward in the case of talismanic magic. A great variety of texts and archeological finds (talismans, amulets, and rings containing stones, teeth, crosses, shells, hair, bones, and herbal and animal materials) show that belief in the general protective power of such objects was widely shared in many societies. ${ }^{34}$ As long as only a general protective power is attributed to such objects, the belief in their efficacy can hardly be falsified. Nonetheless, when specific objects were claimed to be utilizable for specific goals (such as the destruction of a given city, the defeat of a given army, or the failure of a given business in a well-defined moment), we would expect a considerable rate of negative outcomes. Yet there is little indication that negative results discouraged their use or that sceptical attitudes emerged because of the malfunctioning talismans: popular stories were spread about their efficacy despite any negative results, and texts with talismanic content were copied by university students and professors, apparently with the assumption that the texts were valid. ${ }^{35}$

${ }^{33}$ Daryn Lehoux, “Tropes, Facts, and Empiricism,” Perspectives on Science 11 (2003): 326344.

${ }^{34}$ Such medieval and early modern objects are shown in great number in Liselotte Hansmann and Lenz Kriss-Rettenbeck, eds., Amulett und Talisman: Erscheinungsform und Geschichte (Munich: Verlag Georg D. W. Callwey, 1966), while textual amulets are presented in Don Skemer, Binding Words: Textual Amulets in the Middle Ages (University Park: Penn State University Press, 2006).

${ }^{35}$ For the story, see Charles Burnett, "Thābit ibn Qurra the Harrānian on Talismans and the Spirits of the Planets," La Corónica, 36 (2007): 13-40; Jean-Patrice Boudet, Le Recueil des plus célèbres astrologues de Simon de Phares édité pour la société de l'Histoire de France, 2 
But what could have happened when magical methods produced results that undeniably contradicted the underlying magical theory? Even in such cases it would be too "Whiggish" to expect the practitioners to abandon the theory because various explanations could have saved the core hypotheses of magic from falsification. The argument could be always made that the operator was not properly prepared to perform the given magical enterprise: he did not fast enough, or his bodily and spiritual chastity had not reached a satisfactory level. It was also possible to argue that the constellations at the moment of the experiment were not favorable. Or perhaps everything happened as it was described in the magic manuals, only the proper person was not involved. Instead of the democratic ideal of modern science, according to which an experiment carried out under the same specified conditions can be repeated by anyone, anywhere, regardless of gender, race, and origin, in magic only properly initiated persons succeed. ${ }^{36}$ Only adepts could perform the experiments properly, and pupils were not necessarily in the possession of such abilities. If the given result was expected from a helping angel or demon, the argument could have been made that the spirits were able, just not willing, to do what had been required from them. Finally, one could always say that the instructions--originating usually from texts written several hundred years earlier often in a different Arabic or Jewish culture--were not understood properly, or that the text was simply not copied or translated correctly. This last argument was more than plausible; the Picatrix for example was translated from Arabic to Castilian, and then in a second step from Castilian to Latin, and then further small Latin texts were added to it, so the end result was fairly far from the Arabic original. If we add to this picture the fact that many

vols. (Paris, 1997-1999), vol. 2, 257; and Weill-Parot, Les “images astrologiques" au Moyen Âge, 897-900.

${ }^{36}$ The issue of replicability is not without problems in contemporary "hard sciences" either. See the discussion in specific articles in the journal Nature highlighting failures in the reproducibility of laboratory research results (collected and downloadable from the following web page: http://www.nature.com/nature/focus/reproducibility/index.html). 
texts were first translated from Greek to Arabic, or from Greek to Syriac and then from Syriac to Arabic, there is no reason to be surprised about the corruption of the content of the texts. We know furthermore that scribes were not particularly keen on copying correctly the material even if angels' names were at stake and the importance of the precise transmission of the texts to make the prayers efficacious was explicitly emphasized. ${ }^{37}$ Similarly, talismans of magic squares were also often copied with many errors, even though all talismanic texts stressed the importance of reproducing correctly the figures and characters on the talismans. ${ }^{38}$ In short, the argument could be always made that the negative outcome of a magic experiment was not conclusive because the experiment was not performed competently.

All of these arguments are hypothetical. To my knowledge, no explicit reflections have survived on how failed magic experiments were interpreted by their practitioners (although methodological problems regarding astrological prognostications were often spelled out, among which one can mention the often criticized idiosyncrasy of astrological theories, the optical problems that make the observations of celestial phenomena uncertain according to some authors, and the famous argument of Nicholas Oresme concerning the incommensurability of celestial motion that makes it impossible to predict the path of constellations in a reliable manner and which in turn makes it impossible for the astrologer to formulate stable astrological laws). ${ }^{39}$ I do not claim that the assumptions, defensive arguments, and ad-hoc hypotheses required to save magic theories occurred in scholarly debates on the efficacy of magic; instead I offer them as examples of how the modern mind

\footnotetext{
${ }^{37}$ Charles Burnett, "Remarques paléographiques et philologiques sur les noms d'anges et d'esprits dans les traités de magie traduits de l'arabe en Latin," Mélanges de l'École Française de Rome 114 (2002): 657-668.

${ }^{38}$ Láng, Unlocked Books, 83-94.

${ }^{39}$ Láng, "Experience in the Anti-astrological Arguments of Jean Gerson."
} 
can grasp how belief in experiments that appear to us to be nonsensical could have survived for centuries.

Non-falsifying Experiments in History of Science

One further example illustrates that the problems discussed here do not emerge exclusively in the history of magic, but also in the history of science. The existence of experimentum crucis, the crucial experiment that is meant to provide a final decision between rival theories and to demonstrate the falsity of all but one of them, is a myth not only in the history of magic but also in the history of science.

This example involves Galilei Galileo, who posterity considers one of the founding fathers of experimental science. Galileo reported in his books three types of experiments: real experiments that he performed; imaginary experiments that he did not perform personally, but whose outcomes seemed so persuasive and convincing that he did not feel obliged actually to complete; and thought experiments that were not to be performed in practice at all. In his 1638 book, Two New Sciences, Galileo proposed the following experiment in hydrodynamics:

...I filled with water a glass ball that had an opening as narrow as a straw stem...and turned it over with its mouth downward. However, neither the water, although very heavy and suited to falling through air, nor the air, although very light and much inclined to rise in water, will agree, the former to falling out of the hole [of the ball], the latter to rising upon entering [therein]; but remain, both of them, stubborn and perverse [in their places]. On the contrary, as soon as we shall present to that hole a vessel containing red wine, which is only imperceptibly less heavy than water, we shall see it immediately rise slowly in red streaks through the water; and the water, with the same slowness, descend through the wine, without in the least mixing 
together, until finally the ball would be completely full of wine, and all the water would fall to the bottom of the vessel. Now, what should one say, and what arguments should be appealed to, except that there is between water and air an incompatibility that I do not understand, but which, perhaps... ${ }^{40}$

This is the initial situation, and--if we can believe Galileo--the two liquids will slowly change place:

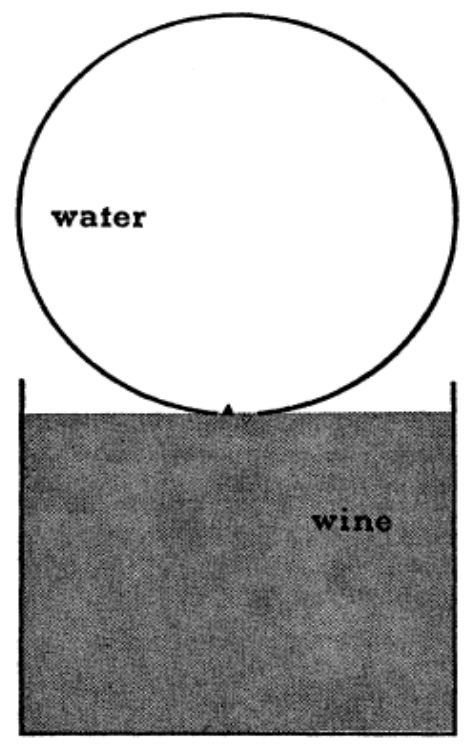

Now the question arises in the skeptical mind: did Galileo really perform this experiment, the outcome of which he admittedly did not understand?

Alexandre Koyré, the famous Galileo scholar, has shown that many famous experiments were never performed by the Italian scientist, and one of these was this very water-wine experiment. In a 1960 article, Koyré claims that the two liquids have fairly similar density, and therefore they have to mix:

I confess that I share Salviati's perplexity. It is, indeed, difficult to put forward an explanation of the astonishing experiment he has just reported; particularly,

40 Quoted in James MacLachlan, “A Test of an 'Imaginary’ Experiment of Galileo's,” Isis 64 (1973): 374-379, 375. 
because, if we repeated it exactly as described, we should see the wine rise in the glass globe (filled with water), and water fall into the vessel (full of wine); but we should not see the water and the wine simply replacing each other; we should see the formation of a mixture.

What is the conclusion? Do we have to admit that red wines of the seventeenth century had properties no longer possessed by the wines of today-properties that made them, like oil, immiscible with water? Or can we suppose that Galileo, who undoubtedly never mixed water with his wine (for wine to him was "the incarnation of the light of the sun"), had never made the experiment; but, having heard of it, reconstructed it in his imagination, accepting the complete and essential incompatibility of water with wine as an indubitable fact? --Personally, I feel that the latter supposition is the right one. ${ }^{41}$

While acknowledging the elegant sense of humor with which Koyré interprets Galileo's text, let me call the reader's attention to the words Koyré is using here: "we SHOULD see the wine rise in the glass globe, and water fall into the vessel, but we SHOULD not see the water and the wine simply replacing each other; we SHOULD see the formation of a mixture." Why does Koyré use "should" instead of "did"?

Did Koyré actually perform this experiment? Or he was so strongly convinced concerning the negative outcome of the experiment that he believed--even without executing it--that Galileo was so strongly convinced about the positive outcome of the experiment that Galileo described it, even without executing it.

In the late summer of 1973, James MacLachlan, another Galileo scholar, filled an after-shave bottle with water and inverted it over a goblet of red wine, and for more than an hour he "watched in fascination as a perfectly clear layer of water formed at the bottom of the

${ }^{41}$ Ibid., 376. 
goblet and became deeper and deeper!"42 (A few hours later, the two liquids finally formed a mixture.) Precisely because the experiment had such an unexpected outcome, MacLachlan believed that Galileo had indeed seen in 1638 (or somewhat earlier) what MacLachlan himself saw in 1971. Thus, the experiment was not an imaginary one for Galileo, but a real one.

But is that certain?

In 1995, Peter Dear, in his famous book Discipline and Experience, referring to this debate, modestly mentions that the water-wine experiment was widely known in the seventeenth century. Among others, the famous Giambattista Della Porta included it in his popular Natural Magick, describing it as a practical joke for making fun of one's friends in the pub. Using a specially made cup that basically mirrors the same experimental setting as was described above (the cup consists of an inverted cone with a narrow hole at the apex, set into a hollow glass ball), a person pours water in the ball and wine in the cone. The two liquids do not mix, because the hole between the two parts of the cup is small. He then drinks first from the wine, and gives the cup to his friend, who drinks second and gets the water. Now, if this friend decides next time to drink first, in order to have the wine, the practicaljoker should keep him talking and simply wait until the two liquids slowly change place, and then give the cup to the victim, who will again drink water. ${ }^{43}$ Dear implies that Koyré and MacLachlan, Galileo scholars who are supposed to know the basic literature read by everyone in the seventeenth century, should have known about the content of Della Porta's book. Precisely because the experiment was widely known, we cannot have the slightest idea whether Galileo performed it personally or only heard about it and described it without

\footnotetext{
${ }^{42}$ Ibid.

${ }^{43}$ Peter Dear, Discipline and Experience: The Mathematical Way in the Scientific Revolution (Chicago: University of Chicago Press, 1995), 144-147.
} 
actually executing it. In either case, it seems that the experiment was real, if not for Galileo, then at least for many of his drunken contemporaries, and it could be performed in the seventeenth century just as well as it can be in our times.

Or perhaps not?

One morning in the summer of 2005 in Budapest, I stood in my bathroom with an empty after-shave bottle in one hand and a glass of some Cabernet Sauvignon from Australia that I was ready to consecrate on the altar of experimental science in the other. I performed the experiment, and what happened? The two liquids did not replace each other; instead, they mixed, giving birth to what we could call a wine "spritzer." Or more precisely, what I saw was that a complete mixture developed above in the after-shave bottle, while a somewhat lighter layer formed in the bottom of the vessel that was slightly more transparent than the red wine.

The conclusion I drew from the negative result of my own experiment was by no means that Galileo and MacLachlan were wrong claiming that the experiment was real and that Koyré was right doubting it. I still believe those who have argued that the experiment can be performed with a positive outcome, and I am convinced that the problem with my attempt was somewhere in my methodology and the materials used: water in Budapest is fairly hard and contains high levels of chlorine, while the red wine that I chose was not some good quality Hungarian wine, but cheap imported wine already mixed with water. In other words, I have applied auxiliary hypotheses in order to convince myself that my experiment was not performed competently, and therefore its negative outcome falsifies nothing.

I have cited this example for several reasons.

First, it demonstrates how earlier convictions may influence sheer perception. In other words, we see what our theoretical background and beliefs allow us to see, even if we are well prepared and cautious historians of science like Alexandre Koyré. There is probably not 
much difference between my confidence that the water-wine experiment can work, even though I did not manage to reproduce it, and the conviction of the medieval reader of Thabit ibn Qurra that scorpions can be expelled from a city with a talisman, even if that reader did not personally manage to execute it.

Second, this example shows that even a detailed description of an experiment is insufficient in itself and does not guarantee that the very same experiment will be repeated in a slightly different age or in a slightly different place, where materials (the wine and the water) and the apparatus are a bit different.

Finally, this case shows something that has become a commonplace in modern philosophy of science and contemporary science studies, ${ }^{44}$ but that has not yet become a widespread idea for the public: there is no such a thing as a crucial experiment. Experiments seem to be crucial, that is apt to decide between two rival theories or to ultimately falsify a given theory, only looking backwards from a time when the decision has finally been made for many different reasons and when there is already a broad consensus on the meaning and the result of the given experiment. Contemporaries rarely deem experiments crucial and final; they often do not even agree on what the result of the experiment was. In all those cases we think an experiment was crucial and decisively falsified a given theory, we can see that many contemporaries actually kept believing in the old theory and did not see the experiment as decisive. They often argued that the experiment produced the non-favorable result only because it was performed incompetently.

To conclude, I believe not only that the initial question (i.e. why theories are kept when experiments do not confirm them or even disconfirm them) is a legitimate inquiry for the history of magic, but also that it is equally legitimate in history of science. We see that the

${ }^{44}$ See, for example, Harry Collins and Trevor Pinch, eds. The Golem: What You Should Know about Science (Cambridge: Cambridge University Press, 1998). See also Kragh, An Introduction, chap. 14. 
answers we can give to it are no less complex in the territory where we tend to believe that experiments actually have true and testable results. 